\title{
The role of landslides in the evolution of a small mountain river valley (Polish Carpathians)
}

Institute of Geography and Spatial Management, Faculty of Geography and Geology, Jagiellonian University in Kraków, Poland; *Corresponding author, E-mail: elzbieta.gorczyca@uj.edu.pl

(Received: February 4, 2020; Revised accepted: August 13, 2020)

https://doi.org/10.18814/epiiugs/2020/020078

In this work we describe the role of landslide processes in shaping river channels and the development of valley floors in $3^{\text {rd }}$ and $4^{\text {th }}$ order catchments in the Polish Flysch Carpathians. The main focus of the study was on the contact zone between the landslide system and the river channel, where it has been shown that $30.2 \%$ of the length of the river network are affected by landslides. Research shows that $93 \%$ of landslides have some form of contact with the river system. Research further shows that the most common contact types in the study are point and area types according to the Korup classification. The most common impacts of landslides on the river channel are riparian and partial occlusion types. Landslides very often cause complete or partial displacement of the river channel, which frequently leads to the blockage of flow, which in turn creates landslide lakes, followed by accumulation zones. The effect of such events is the transformation of the longitudinal profile of the river and the intensification of erosive processes in the contact zone and downstream. Increased activity of erosive processes can lead to the activation of landslide processes, including on the opposite slope.

\section{Introduction}

Landslide processes in the Flysch Carpathians are a common phenomenon. It is estimated that landslides occupy $30-40 \%$ of the Carpathians' area. The development of landslides in the Flysch Carpathians is facilitated by local flysch geologic structure. Shale and shale-sandstone deposits are the most susceptible to the occurrence of landslides processes. Fracture and dislocation zones of sandstone located on more vulnerable layers play an important role in landslide activation (Ziętara, 1968; Bober, 1984; Bajgier, 1994; Poprawa and Rączkowski, 2003; Margielewski, 2008).

Crozier (2010) reviewed theories of evolution of terrain, in which the dominant role is attributed to fluvial processes, often with full marginalization of the role of landslides. However landslide movements are very effective processes shaping the morphology of terrain. They are underestimated in the context of wider, temporal and spatial scales. In many scientific publications, one can find evidence for the important role of landslides in shaping relief as well as the rate of relief change. Crozier (2010) further notes the dominance of landslide processes in the circulation of matter on hillslopes and generally in the evolution of hillslopes.

Flood waters of streams that cause increased lateral erosion also have an important role, which contributes to the loss of hillslope stability and the activation of landslide processes. Such an event leads to the rejuvenation of pre-existing landslides. Landslide material originating from a hillslope can lead to temporary or permanent blockage of the flow of the river, which can create landslide lakes. This phenomena are more frequent in smaller valleys which are more narrow typically. As a result, lateral erosion activity increases, which leads to the widening and deepening of the valley floor (Margielewski, 2008). Particularly large changes within the river channel occur during the formation of landslide dams (Costa and Schuster, 1988; Clague and Evans, 1994; Schuster 2006; Hermanns et al., 2009; Kuo et al., 2011; Cebulski 2014, 2016; Wu et al., 2019; Kumar et al., 2019). According to Costa and Schuster (1988) the most endangered areas are valleys with a narrow floor due to the small area receiving displaced colluvial material. The gradient of valley hillslopes also increases the chance of the formation of landslide dams given the increased rate of landslide movement, which allows the stream to be blocked before the material is eroded and removed by the river. According to Schuster (2006) and Korup et al. (2010), landslide dams have a significant impact on the morphology of mountain valleys, changing them both up and down the river from the landslide dam. The effect of this is the formation of often temporary or permanent lakes, accumulation of sediment in front of dams, changes in river channel patterns, and secondary activity of landslides.

Landslides can be classified according to the type of contact between the river channel and landslides, and the geomorphic consequences of their impact on the river channel. This classification was provided by Korup (2005) in alpine regions of New Zealand. He distinguished 5 types of geomorphic coupling interfaces (area, linear, point, indirect and nil) and 5 types of geomorphic landslide impacts (buffered, riparian, occlusion, blockage, obliteration).

The aim of our study was to determine the role of landslides in the evolution of mountain river channels and valley floors in $3^{\text {rd }}$ order and $4^{\text {th }}$ order river catchments (according to Horton-Strahler method; 
Strahler, 1964) in the Polish flysch Carpathians. Special attention was paid to landslides connecting the valley floor or river channel. A modified Korup classification (2005) was used to study interactions between landslides and the river system. We tested its usefulness in the analysis of the role of landslides in the modification of valley floor relief and fluvial processes in mid-mountains.

\section{Study Area}

The study area is located in the northern part of the Western Carpathians in Poland (Fig. 1). Thirty river valleys were selected for study purposes in the Polish Flysch Carpathians and are located in 5 distinct mountain ranges (successively from the west): Beskid Śląski Mts. (3 catchments), Beskid Żywiecki Mts. (2 catchments), Beskid Wyspowy Mts. (4 catchments), Gorce Mts. (7 catchments), Beskid Sądecki Mts. (5 catchments), Beskid Niski Mts. (6 catchments), and Bieszczady Mts. (3 catchments) (Fig. 1). These areas represent mid-mountains with elevations ranging from $186 \mathrm{~m}$ to $663.3 \mathrm{~m}$. The Gorce Mts., Beskid Śląski Mts., Beskid Żywiecki Mts. and Beskid Sądecki Mts. are compact mountain groups with straight or convex hillslopes. The Bieszczady Mts. and Beskid Niski Mts., on the other hand, are banded mountain ranges with convex-concave hillslopes. The Beskid Wyspowy Mts. are characterized by the occurrence of isolated island-type mountain ranges (Izmaiłow et al., 1995). Some of the studied catchments are characterized by high forest cover, especially at upper elevations. As a result, intensive forest management is observed in many places. Buildings are found throughout the study area, however, a higher building density is observed at lower elevations in the studied catchments.

\section{Methods}

A LIDAR model was used to analyze the morphometric parameters of 30 catchments $\left(3^{\text {rd }}\right.$ order and $4^{\text {th }}$ order) and 344 landslides. Data from aerial LIDAR scanning (regular $1 \times 1 \mathrm{~m}$ grid, *asc files) were obtained from the Central Office for Geodetic and Cartographic Documentation in Poland. The average altitude error for interpolated data does not exceed $0.2 \mathrm{~m}$.

Morphometric analyses were divided into three stages:

1. the first stage consisted of morphometric analysis of landslides: landslide area, average slope, height differences, length and width and height of landslide fronts.

2. the second stage consisted of morphometric analysis of the catchment: total area, area of the valley floor, maximum and minimum height, height differences, gradient of the catchment, length of the main river, length of the river network, density of the river network, and sinuosity of the channel. The length and width of the catchment were also examined to calculate the elongation index. These indicators inform about the shape of the studied catchments.

3 . the third stage of morphometric analysis was designed to examine the contact zones of the landslide system and the river channel or valley floor system. These analyses concerned the length of the contact zones of these two systems, the width of the valley floor and the river channel within the contact zones, as well as areas unaffected by landslide processes. The sinuosity of the studied river within these zones was also estimated.

The area affected by landslides was calculated using a formula expressing the relation of the total area of the landslides in the catchment $(\mathrm{Po})$ to the catchment area without the area of the valley floor (Pr) (Bober, 1984).

$$
O p=\frac{P o}{P r} \times 100 \%
$$

The next step consisted of the calculation of the percentage share of the length of the river network and the main river of the catchment having direct contact with the landslide system.

In order to identify the geologic structure of the catchment and the rock formations on which landslides have developed, we used detailed geologic maps produced in the years $1956-2009$ by the Polish Geo-

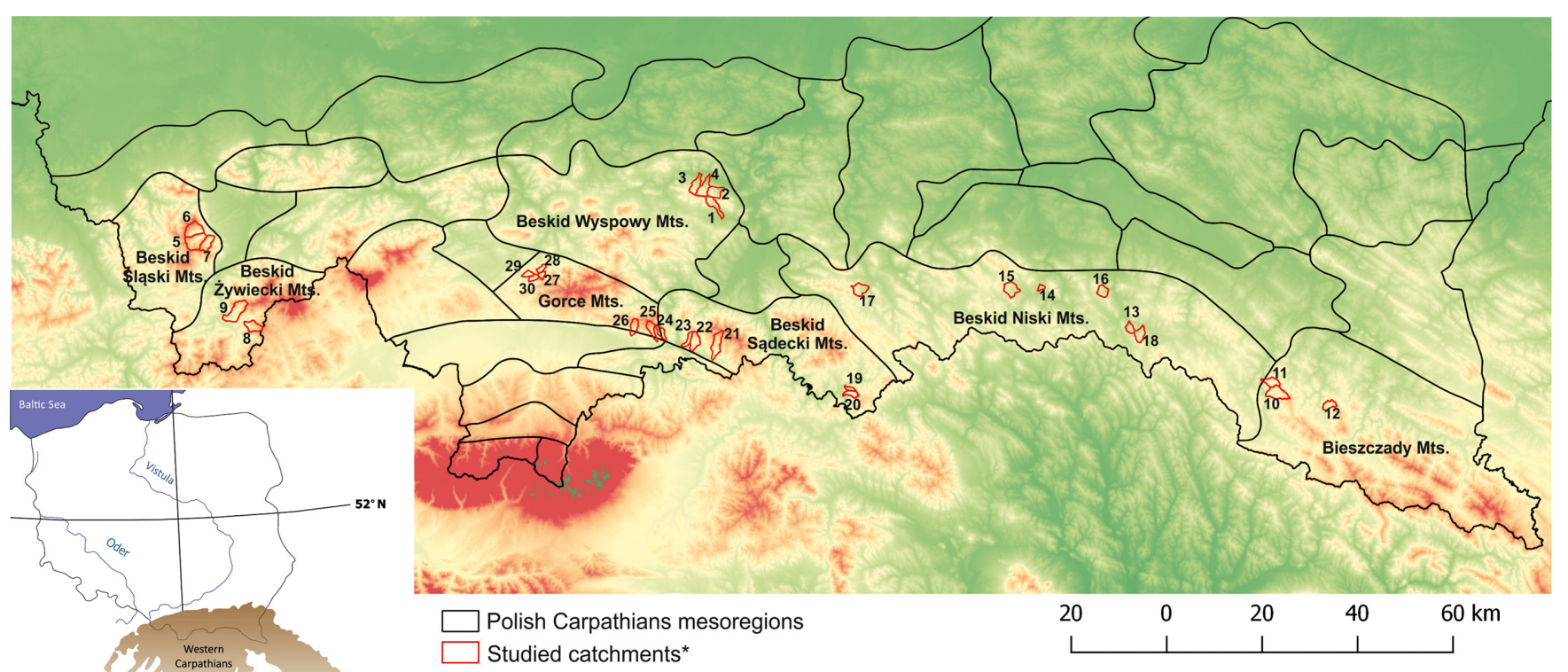

*Studied catchments: 1 Bukowiec, 2 Stańkowski, 3 Jaworzna, 4 Żmiąca, 5 Leśnianka, 6 Malinowski, 7 Twardorzeczka, 8 Straceniec, 9 Nickulina, 10 Olchowaty, 11 Kołodzielny, 12 Walter, 13 Zwadływka, 14 Kotań, 15 Krokowy, 16 Chyrkowski, 17 Szklarka, 18 Ostrzesz, 19 Wilcze, 20 Podgórski, 21 Sielski, 22 Czarny, 23 Kozłecki, 24 Czarna Krośnica, 25 Lubański, 26 Mizerzanka, 27 Głęboki, 28 Porębianka, 29 Worwówka, 30 Za Twarogiem

Figure 1. Location of the study area relative to the mesoregions of the Polish flysch Carpathians (Kondracki 1964). 
logical Institute-National Research Institute (http://baza.pgi.gov.pl). Scanned georeferenced geologic maps were converted to digital maps using manual vectorization, then the area of sediments was measured in the catchment and landslides. This allowed to determine the percentage share of all rock layers in the studied catchments and the share of the rock layers on which landslides are located.

All mapped landslides were classified according to Korup (2005) based on the geomorphic impact interface and impact on the river channel and valley floor. The geomorphic coupling interface consisted of five types.

First is the area type, when the river system is located within a landslide landform. The second type is known as linear, the landslide stretches along the river channel. The third type is called point contact; location of landslide deposits at an approximate right angle relative to the river. Indirect is the fourth type, but it was not used in the present study (landslide enters a body of water). The last type of geomorphic coupling interface is the type nil - observed contact only with the valley floor (no contact with the river channel). Geomorphic impact has seven classes: buffered - no contact between landslide and river channel (contact with the valley floor), riparian - slight contact between systems, increase in lateral erosion, cutting colluvium - cutting of landslide colluvia through the river (new class) (Fig. 2), occlusion - diversion of the river around landslide deposits, partial occlusion - partial diversion of the river around convex landslide deposits (new class) (Fig. 3), blockage - blockage of water flow, formation of landslide lakes, obliteration - complete coverage of the valley floor by landslide deposits, breaking river channel continuity. The classification of landslide impact on the river system was expanded via two new types (described above), which resulted from observations during field studies.

In the next stage, for all types of contact with and impact on the course of the river channel, landslides were identified that directly and significantly influence the course of the river channel by changing its course and disrupting the continuity of the fluvial system - these were named aggressive landslides. Such an impact of the landslides was found over the entire length of the landslide-channel contact, and in other cases for only parts of it. Landslides found across the upper parts of the hillslope were excluded from the classification discussed herein.

All morphometric characteristics of catchments, landslides as well as river valleys and river channels were obtained from the LIDAR model using QGIS software. It was a manual interpretative task and the approach to each catchment was individual. Results of landslides classification were partially verified during field research (in 5 catchments), which confirmed the correctness of the analyzes carried out in the GIS software.

Selected morphometric features of catchments, valley floors, river channels, landslides, and contact zones of river valley and landslide systems were examined via statistical analysis with use of the STATISTICA 13 software. Measures of position such as minimum, maximum, first and third quartiles and median values were calculated for key morphometric features. The number of landslides belonging to

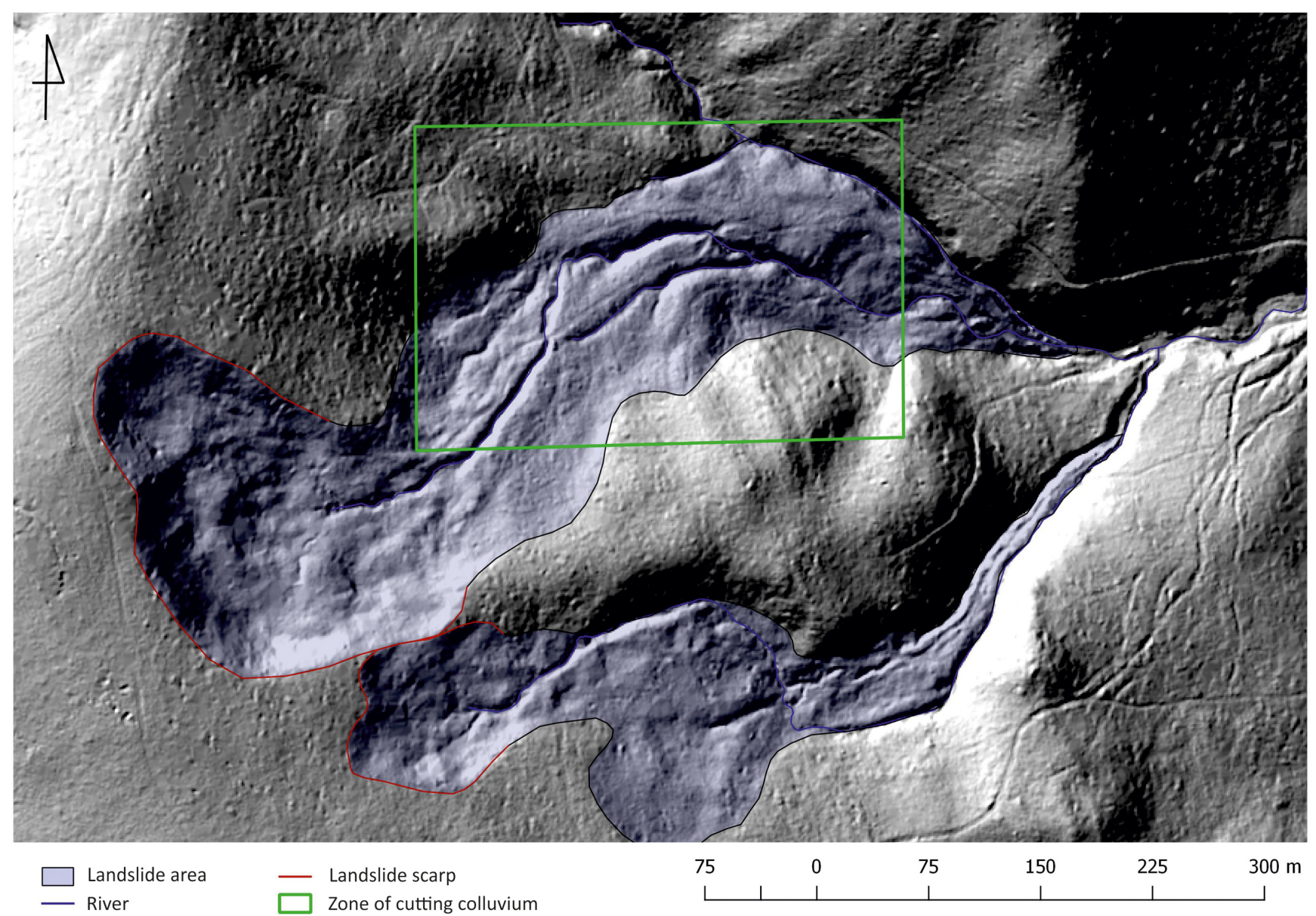

Figure 2. Type of geomorphic impact - cutting colluvium. 


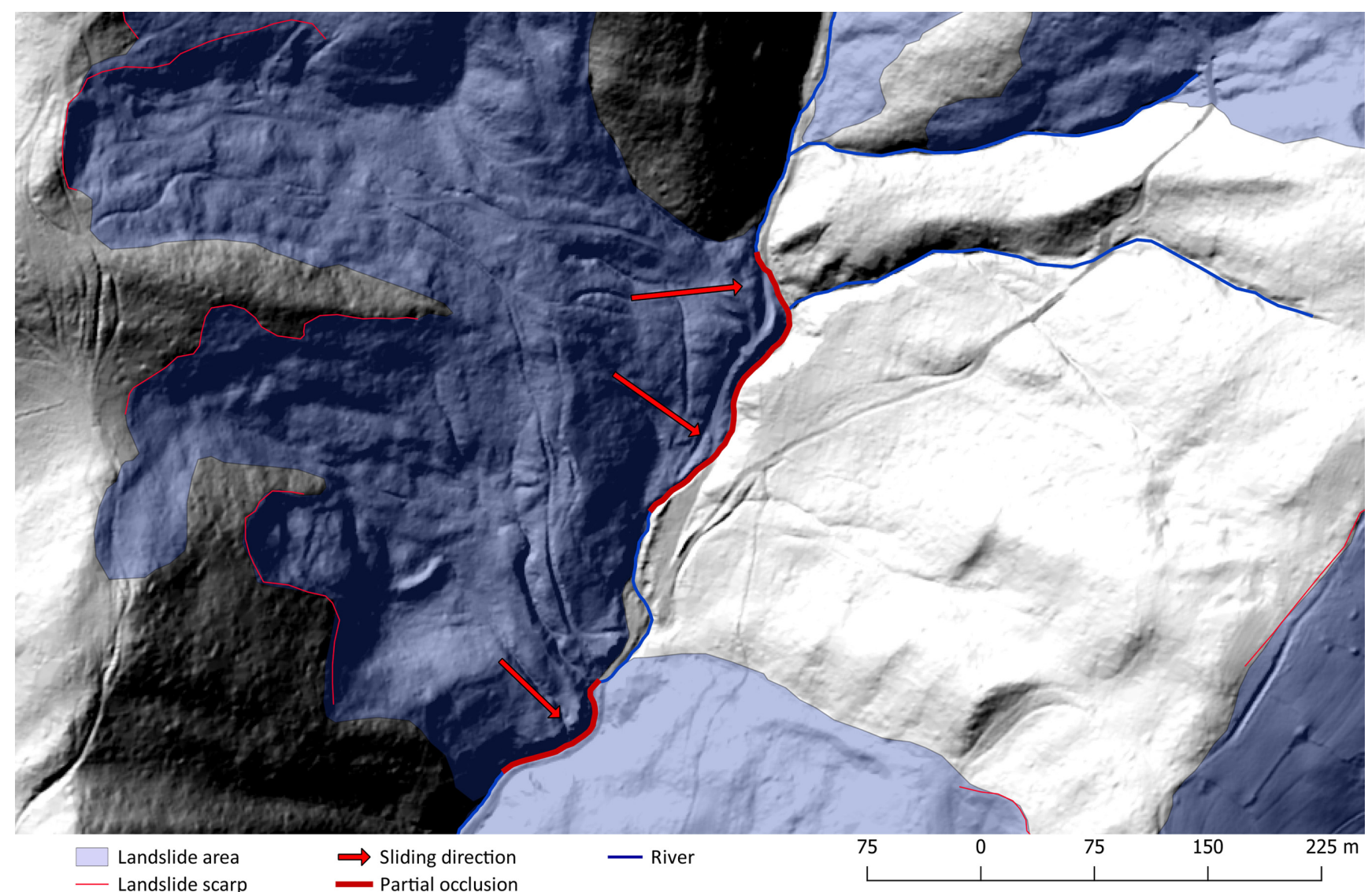

Figure 3. Type of geomorphic impact-partial occlusion.

different types in the Korup (2005) classification was compared for the studied catchments as well. In addition, the arithmetic mean was calculated for selected morphometric features for different types of landslides: 1) aggressive landslides, 2) landslides reaching a valley floor or river channel, and 3) landslides without contact with valley floor. As the sample of studied features does not follow a normal distribution, the statistical significance of the detected differences was tested with the use of the Mann-Whitney $U$ test and the Kruskal-Wallis $H$ test. Differences were considered statistically significant if the $\mathrm{p}$-value was 0.05 or lower. Spearman's rank correlation coefficients were calculated for selected morphometric features separately for aggressive landslides and for those not generating such impact on the river channel.

\section{Results}

\section{Characteristics of the Studied Catchments}

The study area included 30 catchments located in the Polish flysch Carpathians. Catchment areas ranged from $1.3 \mathrm{~km}^{2}$ to $17.6 \mathrm{~km}^{2}$. The length of their river networks ranged from 5.1 to $30.1 \mathrm{~km}$. The length of the main river channel ranged from 1.8 to $7.3 \mathrm{~km}$. The highest measured density of the river network was $4.8 \mathrm{~km} / \mathrm{km}^{2}$, whereas the lowest was $1.06 \mathrm{~km} / \mathrm{km}^{2}$ (Table 1 ). The highest channel sinuosity was 1.29 . The range of the most frequent river channel sinuosity values extended from 1.07 to 1.15 . The lowest channel sinuosity index value was 1.03 (Table 1). The catchment elongation index is the quotient of the diam- eter of a circle with an area equal to the catchment area and the length - it was measured for each of the 30 catchments. These analyses showed that elongated catchments predominate in the studied sample. The vast majority of the studied catchments had an elongation index close to 0.69 . The highest calculated catchment elongation index value in our study was 0.93 (Table 1).

\section{Characteristics of Landslides in the Studied Catchments}

A total of 344 landslides were mapped in the study area. The average area of the studied landslide area was $0.31 \mathrm{~km}^{2}$. The largest identified landslides had an area of $1.85 \mathrm{~km}^{2}$. The share of the study area affected by landslides was $27.14 \%$ in the studied catchments and varied strongly from one catchment to another. The highest share of a catchment's area affected by landslides was $77 \%$. However this value is an outlier. The next highest share of a catchment's area affected by landslides was $49.15 \%$. Research has shown that the smallest share of area affected by landslides in a single catchment was $5.58 \%$ (Fig. 4).

The catchments studied in the Polish flysch Carpathians are dominated by shale and sandstone. The area is located across three different geologic units (Magura, Dukla and Silesian units). The Magura unit rock formations are composed mainly of thick and thin-sided sandstone with an admixture of conglomerate and shale (Chylak and Wrężlewicz, 2009). The Dukla unit is characterized by alternating thin sandstone and shale - hieroglyphic layers as well as the occurrence of clayey dark gray shale and sandstone thin-sided inoceramus layers (Jankowski, 2015). The Silesian unit is characterized by the occur- 
Table 1. Catchment and main river morphometric features

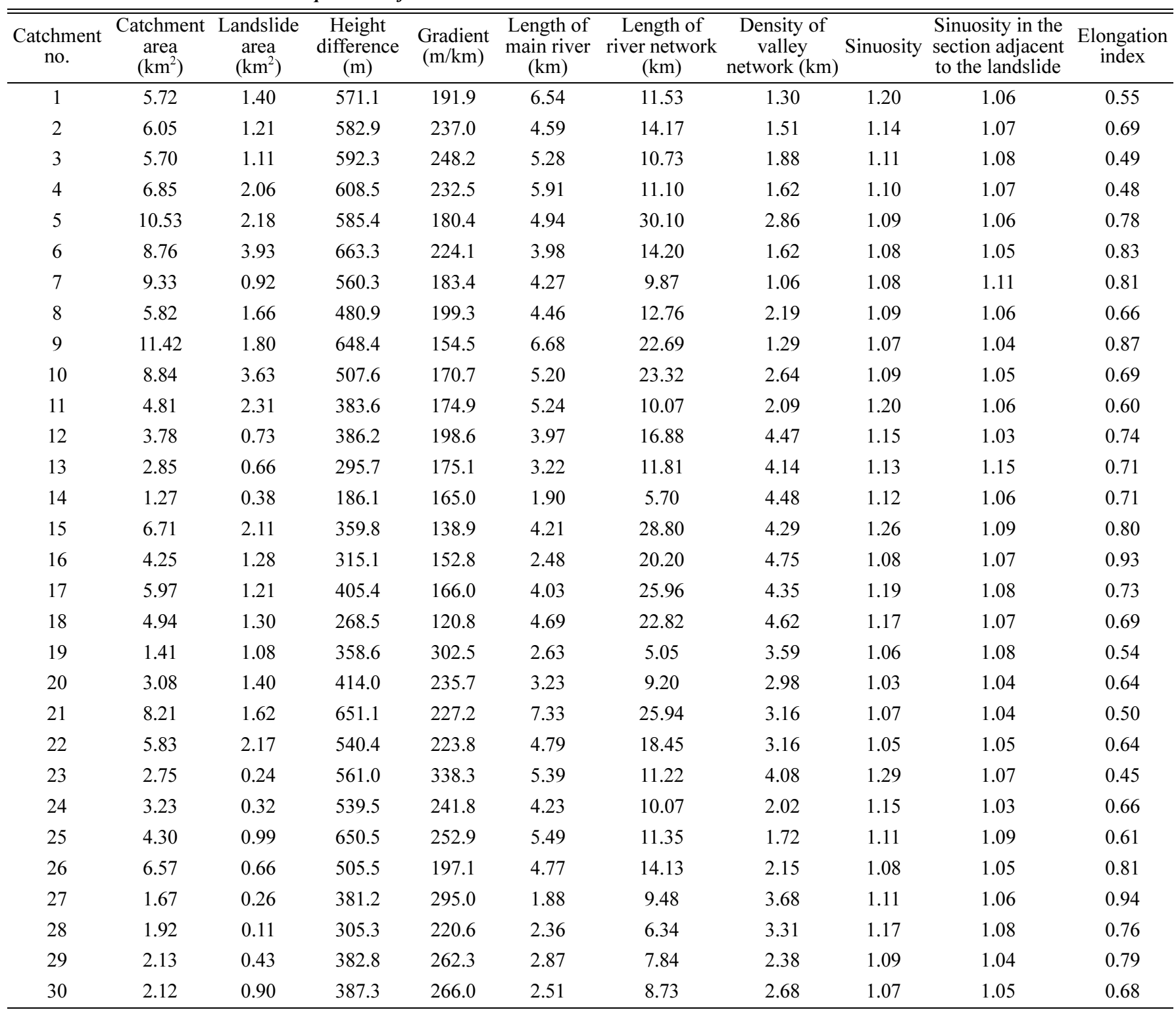

rence of thick-layered sandstone with shale and fine and medium layered sandstone, as well as mudstone and shale (Haczewski et al., 2007). Sandstone-dominated layers prevail in the majority of the studied catchments $(60.5 \%$ of study area). Shale-dominated layers occupy $39.5 \%$ of the study area. The share of sandstone and shale varies substantially in the studied catchments (Fig. 5). Similarly, the landslide distribution reflects the general lithology of the study area. About $16.1 \%$ of the catchments' area is occupied by landslides found atop sandstone-dominated layers and $9.5 \%$ found atop shale-dominated layers (Fig. 5).

\section{Interaction Between Landslides and the River System}

According to the Korup classification (2005) the dominant type of geomorphic coupling interface between landslides and the river system is the point type, which was identified for 213 landslides, representing $66.6 \%$ of all the landslides in the study area and $62 \%$ of the landslides' area. The area type of landslide-river coupling was observed in 70 landslides (30.1\% of the landslides' area). The linear and nil types of landslide-river coupling are the rarest of the identified types occupying $3.5 \%$ and $3.4 \%$ of the studied landslides' surface area, respectively). The Korup classification showed that $93.0 \%$ of the studied landslides have contact with the river channel or valley floor, which means that only 24 landslides have no contact with the river channel and valley floor of the 30 catchments studied (Table 2-3, Fig. 6).

The Korup geomorphic impact classification (2005) asserts that the most common impact type is the riparian type of landslide impact (42.8\% of landslides), but the partial occlusion type affects a larger area than the riparian type. Landslides with the partial occlusion impact type occupy $38.4 \%$ of landslides' area, whereas landslides with the riparian type of impact occupy $25.6 \%$. The occlusion type of impact occurred in $11.9 \%$ of landslides ( $14 \%$ of the studied landslides' area), and the cutting colluvium type was observed in $5.9 \%$ of landslides $(7.9 \%$ of landslides' area). Only $3.1 \%$ of the studied landslides belonged to the obliteration type of landslide impact, whereas the blockage type of impact was found in only $0.3 \%$ of landslides (Table $4-5$, Fig. 7). 


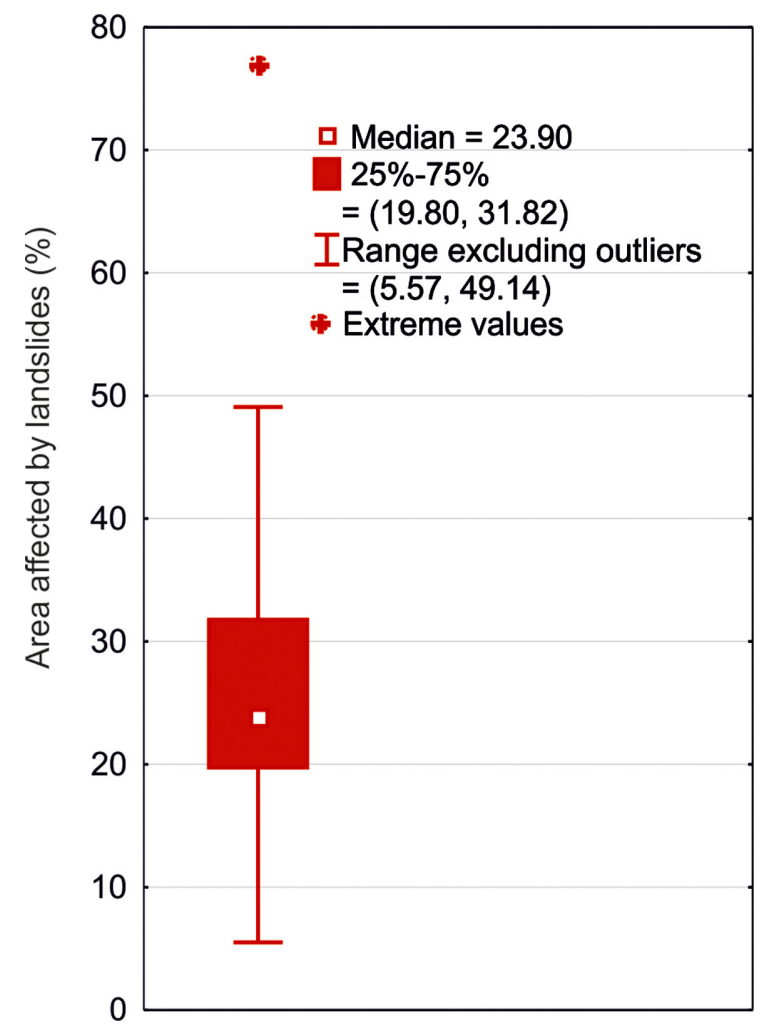

Figure 4. Percentage of area affected by landslides in the study area in the Polish flysch Carpathians.
In total, $30.2 \%$ of the river network length and $40.8 \%$ of the main river channel length has contact with landslides in the study area. These values, however, strongly vary from catchment to catchment.

The middle $50 \%$ of the width of the studied valley floors ranged from 13.2 to $38.0 \mathrm{~m}$ (average of $28.3 \mathrm{~m}$ ) in channel reaches without contact with landslides, but ranging from 1.2 to $11.0 \mathrm{~m}$ (average of $11.1 \mathrm{~m}$ ) in channel reaches affected by landslides (Fig. 8). The exception in this study is the maximum value of $168.2 \mathrm{~m}$, which was measured in the lower part of the Lubański Stream catchment in the Gorce Mts. The strongest narrowing of the valley floors occurs in places where the river channel is adjacent to landslides with occlusion (on average $7.5 \mathrm{~m}$ ).

The width of river channels is also affected by landslides. The middle $50 \%$ of the width of channels ranged from 2.8 to $4.6 \mathrm{~m}$ (on average $4.0 \mathrm{~m}$ ) in reaches not affected by landslides, and 1.1 to $3.8 \mathrm{~m}$ (on average $2.7 \mathrm{~m}$ ) in places where landslides have contact with the river channel (Fig. 9).

A considerable decrease in river channel sinuosity occurs in river channel reaches affected by landslides. The mean river channel sinuosity was calculated to be 1.12 for the analyzed catchments - it equals only 1.05 for reaches affected by landslides, with a maximum of 1.15 , while for reaches not affected by landslides it is 1.29 (Fig. 10).

Our study pays special attention to aggressive landslides strongly affecting river channel geometry and functioning. Aggressive landslides constitute $43 \%$ of all landslides in the catchments. These landslides are larger (2.7 times, on average), longer (1.4 times, on average), and are characterized by greater height differences (Table 6) than other landslides. The length of the contact line of landslide colluvium with

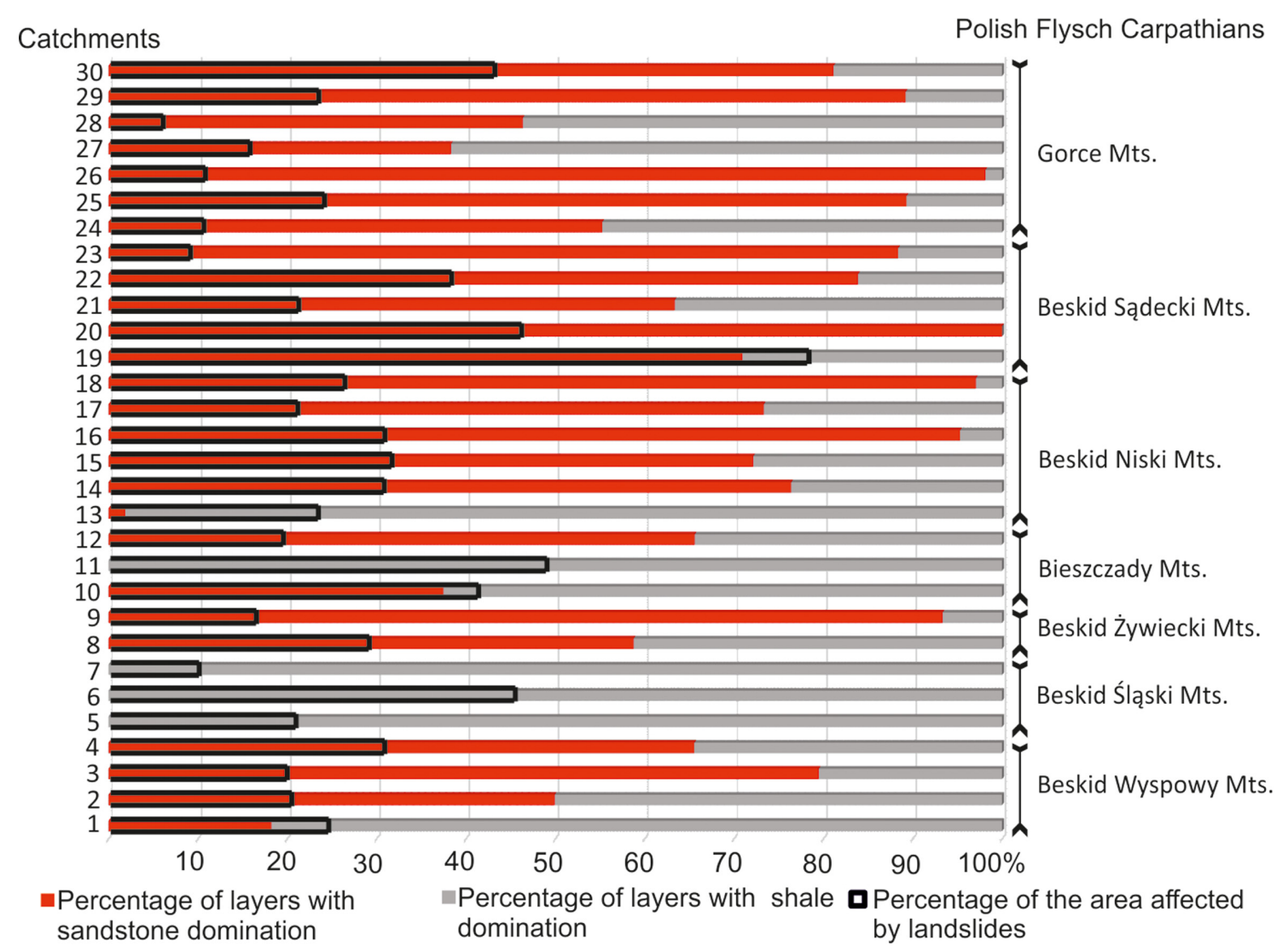

Figure 5. Percentage of rock layers (sandstone- and shale-dominated) in the study area in the Polish flysch Carpathians and percentage of area affected by landslides. 
Table 2. Morphometric characteristics of landslides-river channel coupling types

\begin{tabular}{|c|c|c|c|c|c|c|c|c|c|c|c|c|}
\hline \multirow{2}{*}{$\begin{array}{l}\text { Geomorphic } \\
\text { coupling interface }\end{array}$} & \multicolumn{3}{|c|}{ Area (ha) } & \multicolumn{3}{|c|}{ Length (m) } & \multicolumn{3}{|c|}{ Width (m) } & \multicolumn{3}{|c|}{ Length of contact section (m) } \\
\hline & $\mathrm{Q}^{\mathrm{a}}$ & $\mathrm{Q}^{\mathrm{b}}$ & Median & $\mathrm{Q}^{\mathrm{a}}$ & $\mathrm{Q}^{\mathrm{b}}$ & Median & $\mathrm{Q}^{\mathrm{a}}$ & $\mathrm{Q}^{\mathrm{b}}$ & Median & $\mathrm{Q}^{\mathrm{a}}$ & $\mathrm{Q}^{\mathrm{b}}$ & Median \\
\hline Point & 1.9 & 14.8 & 3.9 & 156.7 & 436.2 & 272.1 & 126.9 & 330.7 & 209.6 & 153.5 & 435.7 & 275.1 \\
\hline Area & 3.5 & 20.5 & 8.9 & 254.7 & 596.7 & 362.0 & 147.1 & 387.7 & 233.9 & 194.8 & 752.3 & 373.3 \\
\hline Nil & 1.4 & 4.3 & 3.2 & 140.9 & 275.7 & 208.5 & 107.2 & 263.7 & 162.4 & 94.0 & 251.3 & 132.8 \\
\hline Linear & 3.7 & 24.3 & 13.2 & 260.4 & 604.8 & 518.8 & 126.5 & 458.3 & 240.4 & 305.8 & 1160.8 & 668.3 \\
\hline No contact & 0.8 & 3.0 & 1.4 & 114.3 & 215.4 & 171.7 & 61.5 & 203.4 & 97.8 & - & - & - \\
\hline
\end{tabular}

a $25 \%$ quartile.

b75\% quartile.

Table 3. Share of landslides and area and total length of the contact section for landslides assigned to selected geomorphic coupling types

\begin{tabular}{|c|c|c|c|c|}
\hline Geomorphic coupling interface & Number & Share of landslides & Share of landslide area & Total length of contact section $(\mathrm{km})$ \\
\hline Point & 213 & 66.6 & 60.6 & 77.0 \\
\hline Area & 70 & 21.9 & 30.1 & 46.0 \\
\hline Nil & 26 & 8.1 & 3.4 & 5.2 \\
\hline Linear & 11 & 3.4 & 3.5 & 8.9 \\
\hline No contact & 24 & 7.0 & 2.4 & - \\
\hline
\end{tabular}

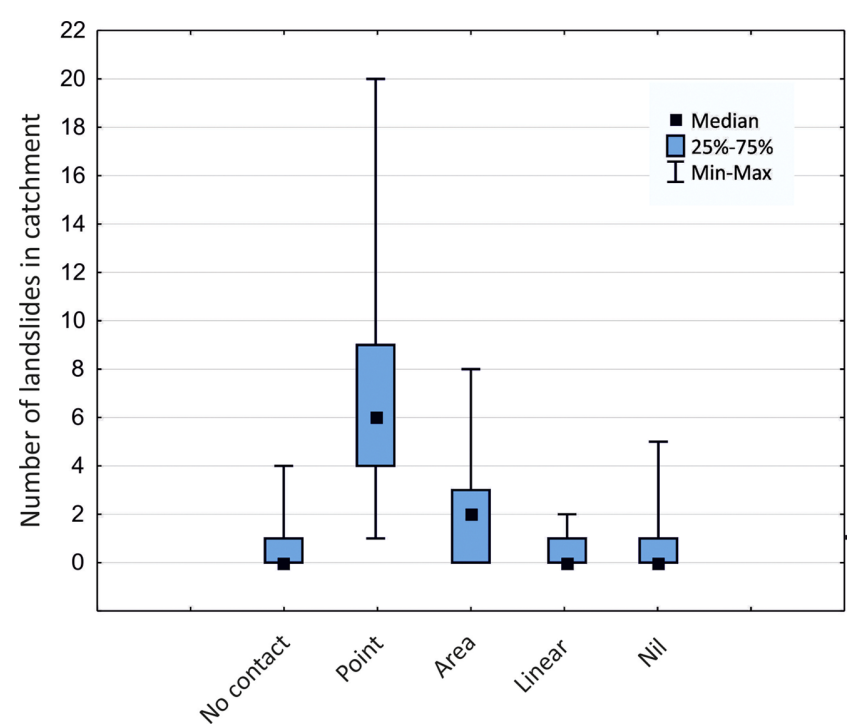

Figure 6. Number of landslides with a different geomorphic coupling interface with the river channel in catchments in the study area.

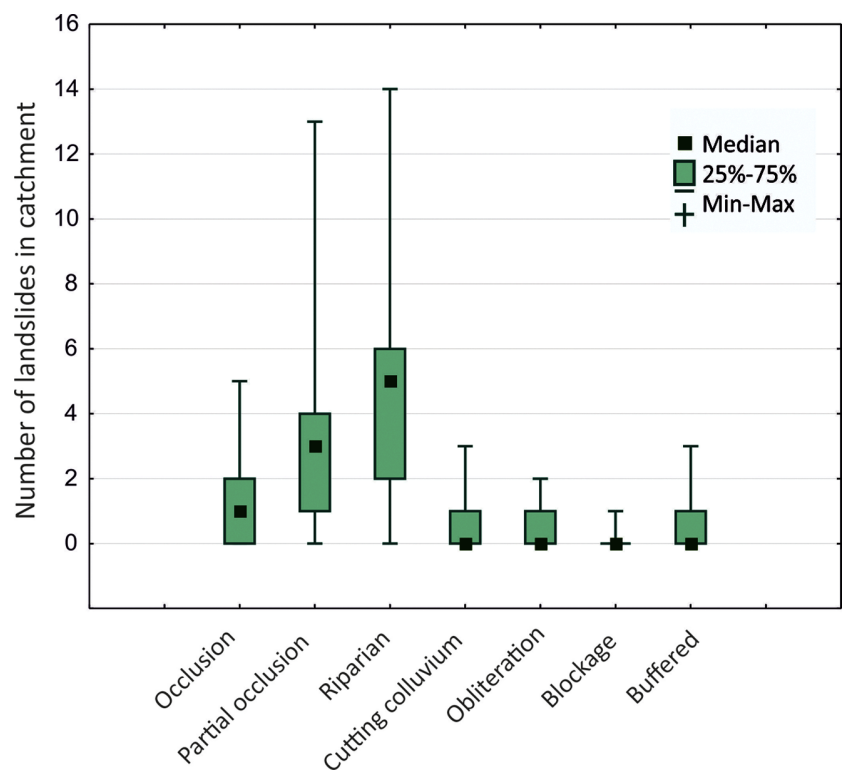

Figure 7. Number of landslides with different geomorphic impact on river channels in catchments in the study area.

Table 4. Morphometric characteristics of landslides yielding different types of impact on the river channel

\begin{tabular}{|c|c|c|c|c|c|c|c|c|c|c|c|c|}
\hline \multirow{2}{*}{ Geomorphic impact } & \multicolumn{3}{|c|}{ Area (ha) } & \multicolumn{3}{|c|}{ Length (m) } & \multicolumn{3}{|c|}{ Width (m) } & \multicolumn{3}{|c|}{ Length of contact section (m) } \\
\hline & $\mathrm{Q}^{\mathrm{a}}$ & $\mathrm{Q}^{\mathrm{b}}$ & Median & $\mathrm{Q}^{\mathrm{a}}$ & $\mathrm{Q}^{\mathrm{b}}$ & Median & $\mathrm{Q1}^{\mathrm{a}}$ & $\mathrm{Q}^{\mathrm{b}}$ & Median & $\mathrm{Q}^{\mathrm{a}}$ & $\mathrm{Q}^{\mathrm{b}}$ & Median \\
\hline Occlusion & 1.6 & 17.2 & 4.76 & 160.1 & 582.4 & 304.2 & 84.4 & 441.4 & 147.5 & 114.0 & 442.9 & 186.8 \\
\hline Partial occlusion & 3.4 & 20.7 & 13.2 & 185.0 & 509.1 & 332.3 & 168.0 & 299.6 & 256.1 & 222.8 & 621.3 & 338.0 \\
\hline Riparian & 1.9 & 9.7 & 3.3 & 158.1 & 369.6 & 263.9 & 263.7 & 299.6 & 186.0 & 130.6 & 417.4 & 231.2 \\
\hline Cutting colluvium & 2.7 & 16.2 & 4.03 & 191.5 & 651.3 & 410.1 & 147.5 & 663.8 & 183.8 & 221.5 & 803.4 & 373.3 \\
\hline Obliteration & 7.0 & 52.3 & 18.8 & 410.3 & 926.7 & 650.6 & 239.3 & 923.4 & 357.7 & 374.6 & 1190.3 & 561.9 \\
\hline Blockage & 76.3 & 76.3 & 76.3 & 593.6 & 593.6 & 593.6 & 923.4 & 923.4 & 923.4 & 1148.0 & 1148.0 & 1148.0 \\
\hline Buffered & 1.4 & 4.5 & 2.96 & 153.8 & 306.3 & 221.2 & 110.6 & 263.7 & 162.4 & 89.7 & 202.0 & 128.4 \\
\hline
\end{tabular}

a $25 \%$ quartile.

${ }^{\mathrm{b}} 75 \%$ quartile. 
Table 5. Percentage of landslides and area and total length of contact section for landslides assigned to selected types of geomorphic impact

\begin{tabular}{ccccc}
\hline \hline Geomorphic impact & Number of landslides & Share of landslides & Share of landslide area & Total length of contact section $(\mathrm{km})$ \\
\hline Occlusion & 38 & 11.9 & 14.0 & 15.4 \\
Partial occlusion & 95 & 29.7 & 38.4 & 48.6 \\
Riparian & 137 & 42.8 & 25.6 & 43.9 \\
Cutting colluvium & 19 & 5.9 & 7.9 & 23.5 \\
Obliteration & 10 & 3.1 & 6.8 & 8.1 \\
Blockage & 1 & 0.3 & 1.8 & 1.2 \\
Buffered & 20 & 6.3 & 3.2 & 4.4 \\
\hline
\end{tabular}

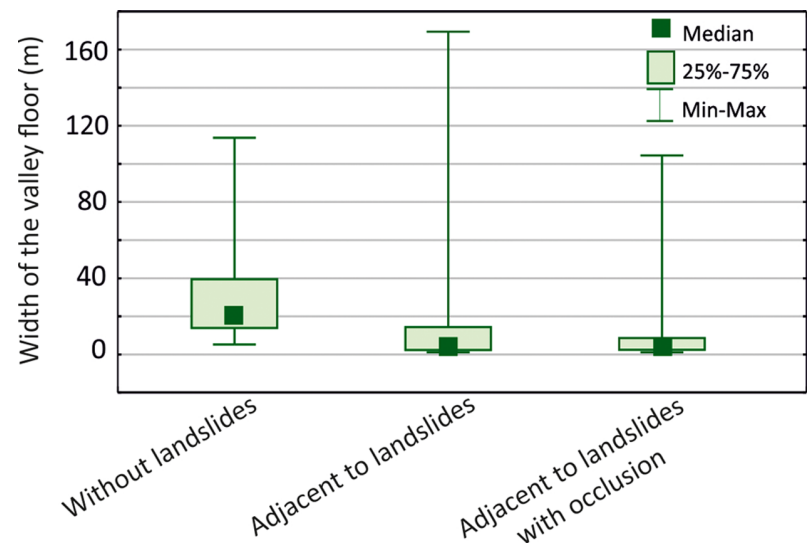

Figure 8. Width of the valley floor in the study area in the Polish flysch Carpathians.

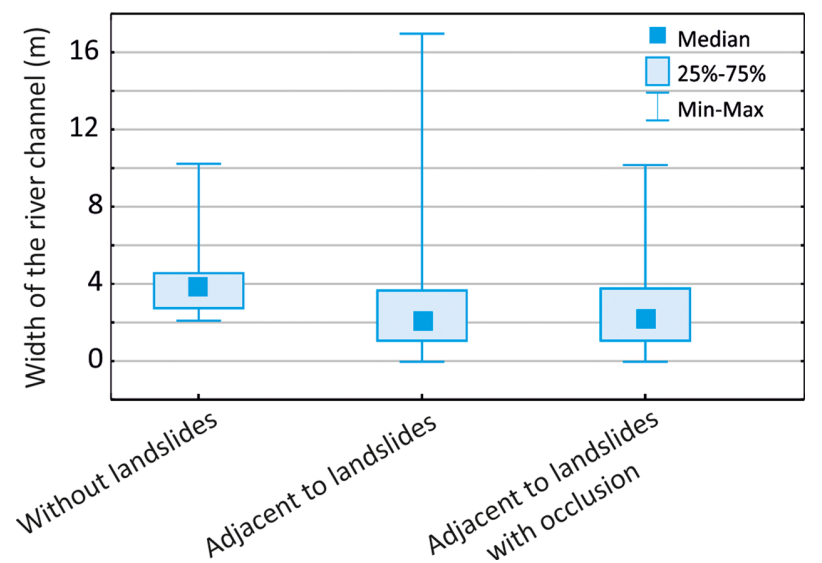

Figure 9. Width of the river channel in the study area in the Polish flysch Carpathians.

the valley floor and the river channel is greater in the case of these landslides than for other landslides. Moreover, aggressive landslides are characterized by a larger number of secondary scarps than other landslides (on average 1.9 times) and a height of landslide front, on average $14.3 \mathrm{~m}$ (Table 6). These differences are statistically significant at 0.0001 . Moreover, the analyzed parameters are more closely correlated in the case of aggressive landslides than in the case of other types of landslides.

Aggressive landslides impact river channels mainly via partial occlusion and occlusion.

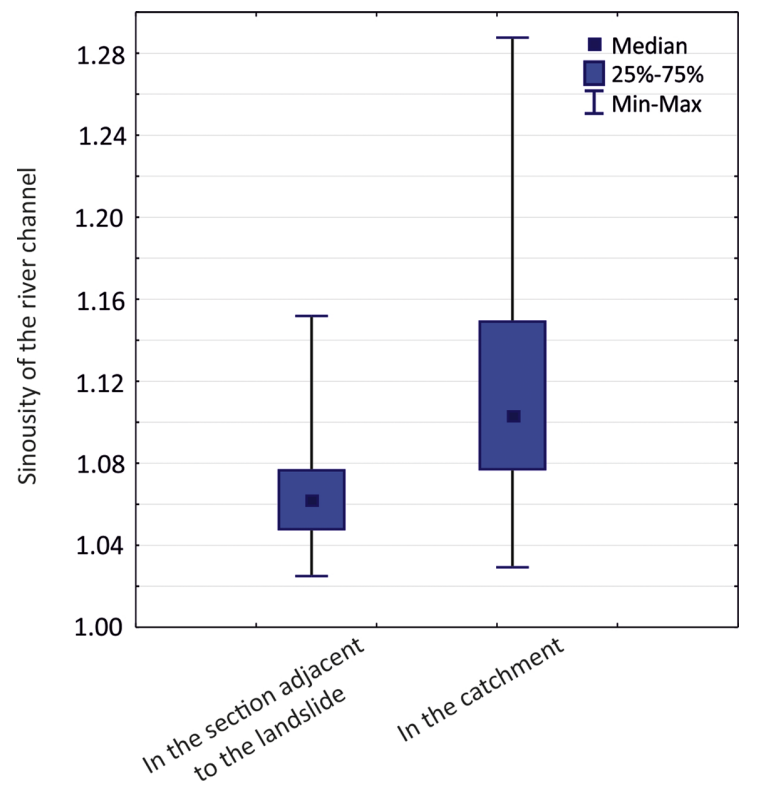

Figure 10. Sinuosity of the river channel in the study area in the Polish flysch Carpathians.

\section{Discussion}

In the Polish Carpathians, the problem of landslides is significant. Today there is one landslide for every square kilometer of the Carpathians. The average area affected by landslides in some catchments (without the area of the valley floor) is $30 \%$ to $40 \%$, but sometimes reaching 70\% (Poprawa and Rączkowski, 2003; Rączkowski, 2007; Wojciechowski et al., 2012). According to national and regional landslide databases, cited by Van Den Eeckhaut and Hervás (2012), there are over 633,000 identified landslides in Europe, of which the majority are found in Italy. There are more than 10,000 identified landslides per country in Poland, Slovakia, Austria, the Czech Republic, France, Norway and the United Kingdom. According to Raczkowski (2007) in Poland there are about 23,000 landslides. For comparison, only $13 \%$ of the Korshrostam area of Iran is affected by landslides (Uromeihy and Mahdavifar, 2000), in New Zealand (South Westland and Fiordland) it is $2.4 \%$ (Korup, 2005), whereas in Japan it is $2.9 \%$ in Chuetsu in Niigata Prefecture (Wang et al. 2007). In the study area in the Polish flysch Carpathians ( $3^{\text {rd }}$ order and $4^{\text {th }}$ order catchments), the percentage of area affected by landslides is $27.1 \%$. Landslide coverage, however, strongly varies by studied area. The highest percentage 
Table 6. Characteristics of aggressive landslides compared with other types of landslides

\begin{tabular}{|c|c|c|c|c|c|}
\hline Landslide parameters & $\begin{array}{c}\text { Average for } \\
\text { all studied } \\
\text { landslides } \\
(344)\end{array}$ & $\begin{array}{l}\text { Average for "non-aggres- } \\
\text { sive" landslides with con- } \\
\text { tact with the valley bottom } \\
\text { or river channel (165) }\end{array}$ & $\begin{array}{c}\text { Average for } \\
\text { aggressive } \\
\text { landslides (151) }\end{array}$ & $\begin{array}{l}\text { Average for land- } \\
\text { slides without } \\
\text { contact with the } \\
\text { valley (28) }\end{array}$ & $\begin{array}{l}\text { Statistical significance of } \\
\text { differences based on the } \\
\text { Kruskal-Wallis / U } \\
\text { Mann-Whitney test }\end{array}$ \\
\hline Landslide area (ha) & 12.4 & 7.6 & 19.3 & 3.8 & $\mathrm{H}=38.46 \mathrm{p}<0.0001$ \\
\hline Landslide height difference (m) & 104.5 & 99.5 & 117.3 & 66.9 & $\mathrm{H}=17.88 \mathrm{p}=0.0001$ \\
\hline Landslide length (m) & 362.9 & 320.4 & 441.5 & 201.6 & $\mathrm{H}=26.13 \mathrm{p}<0.0001$ \\
\hline $\begin{array}{l}\text { Length of contact zone between landslides } \\
\text { and river channel or valley floor }(\mathrm{m})\end{array}$ & 433.5 & 310.8 & 571.2 & N/A & $\mathrm{U}=8721.00 \mathrm{p}<0.0001$ \\
\hline $\begin{array}{l}\text { Length of contact zone between landslides } \\
\text { and river channel - aggressive landslide }(\mathrm{m})\end{array}$ & 346.2 & N/A & 346.2 & N/A & not applicable \\
\hline $\begin{array}{l}\text { Length of contact zone between landslides } \\
\text { and river channel }(\mathrm{m})\end{array}$ & 430 & 318.6 & 562.1 & N/A & $\mathrm{U}=29.30 \mathrm{p}<0.0001$ \\
\hline $\begin{array}{l}\text { Length of contact zone between landslides } \\
\text { and valley floor }(\mathrm{m})\end{array}$ & 404.5 & 299.0 & 529.5 & N/A & $\mathrm{U}=8610.00 \mathrm{p}<0.0001$ \\
\hline Number of secondary scarps & 1.9 & 1.6 & 2.7 & 0.6 & $\mathrm{U}=8663.00 \mathrm{p}<0.0001$ \\
\hline $\begin{array}{l}\text { Height of landslide front } \\
\text { - aggressive landslide }(\mathrm{m})\end{array}$ & 14.3 & N/A & 14.3 & N/A & not applicable \\
\hline
\end{tabular}

of a catchment's area affected by landslides is $77 \%$ and the smallest is $18.9 \%$.

The high activity level of landslide processes in the Polish Carpathians is associated with various factors including extreme precipitation (Rączkowski and Mrozek, 2002; Poprawa and Rączkowski, 2003; Gorczyca, 2004; Wojciechowki et al. 2012), but also type of relief (deeply incised valleys, large gradient), regional tectonics (fault zones, tectonic dislocations) and regional geologic structure (Długosz, 2011). Many authors (Ziętara, 1968; Bober, 1984; Bajgier, 1994; Margielewski, 2008) indicate that geological structure is one factor determining the distribution of landslides in the flysch Carpathians. In the Polish flysch Carpathians shale and shale-sandstone are particularly susceptible to landslide processes. Layers with a predominance of sandstone over shale dominate in the studied area, which is why most landslides are located within such areas. The location of landslides is not dependent on the occurrence of particular rock layers. The percentage of area affected by landslides is similar for shale layers and sandstone layers. However, our study does not allow for unambiguous determination of the most susceptible layers for landslides processes.

In the studied $3^{\text {rd }}$ order and $4^{\text {th }}$ order catchments in the Polish flysch Carpathians as much as $93.02 \%$ of landslides make contact with the valley floor or river channel. On the other hand, in New Zealand (Korup, 2005 ), only $27 \%$ of landslides reach the valley floor. This result indicates the very high pressure of landslides on the river system in the Carpathian area. This may be due to a predominance of elongated catchments with relatively short hillslopes. Landslides in the study area in the Polish Carpathians affect $30.2 \%$ of the river network length and $40.8 \%$ of the length of the main river. In New Zealand, these values are lower: $6.3 \%$ and $27.3 \%$, respectively.

Landslides are an important control of the valley floor and river channel morphology as well as of the river profile form (Ouimet et al., 2007). Colluvial masses reaching the valley floor and river channel lead to a reduction in valley floor width and river channel width. The magnitude of such changes depends on the type of landslide contact with the river system. Reducing the width of the valley floor and the river channel causes a significant decrease in a river's sinuosity.
Type of geomorphic impact of landslides and the location of the landslide-river interface determines the magnitude of the impact of a landslide on a river channel and valley floor. Landslides yielding the riparian type of impact intensify fluvial erosion (mainly lateral erosion) within the contact zone (Korup, 2005), which may relieve the lower part of the colluvial landslide and lead to further development of the landslide. Landslides with occlusion or partial occlusion type of impact have a much larger impact on the development of the valley floor and the river channel. Landslides with occlusion lead to a sudden narrowing of the valley floor and a diversion of the river channel around the convex colluvium of the landslide (Korup, 2005).

Similar development scenarios for different types of landslide-river system coupling were identified in the studied third and fourth order catchments. These scenarios are shown in the conceptual model below (Fig. 11). Landslides with point contact with partial occlusion promote lateral erosion, which leads to undercutting and removal of colluvial material, and the river channel returns to its original course if the colluvia are not very thick. However in places, where the landslide colluvia are thick, a river becomes dislocated permanently and lateral erosion is intensified on the opposite hillslope of the valley (Fig. 11a). Sometimes river completely returns to its old river channel, but with reduced sinuosity (b). Landslides with linear type of contact (c) usually intensify lateral erosion, which causes undercutting of the landslide toe. Landslides with the cutting colluvium impact type are characterized by intensified incision, chaotic arrangement of poorly developed valleys and burial of river channels with a large number of boulders (d). In contrast, landslides with the obliteration type of impact are characterized by river channels completely buried with colluvial material as well as the interruption of the fluvial system and displacement of the river channel below the buried section (e) (Fig. 11).

Korup (2005) showed that in New Zealand landslides most often make contact only with the floor of the valley, without direct contact with the riverbed. Moreover, the most common type of landslide contact with the river system is point contact. In most cases riparian and occlusion type of impact were initiated there. Area and linear types of contact are less common in New Zealand. In the Polish flysch Car- 


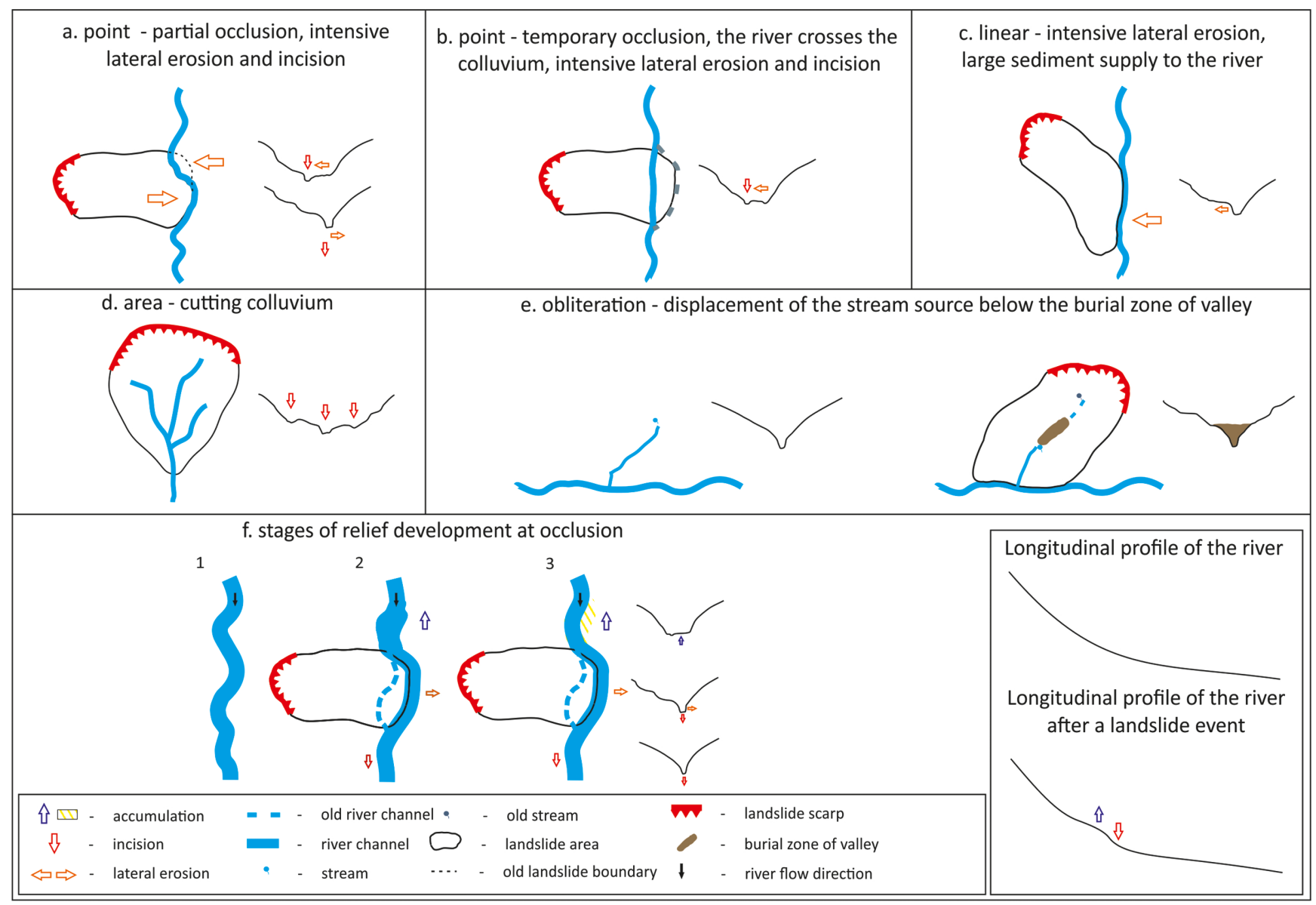

Figure 11. Development models of landslide and river channel coupling in third-and fourth-order catchments.

pathians the most common type is the area type of geomorphic coupling interface and the riparian type of impact.

By far, blockage yields the biggest impact on the transformation of the valley floor and the river channel. They form landslide lakes where sediments accumulate. Lateral erosion is intensified within the contact zone also, which can activate landslide processes. Below the contact zone, intense incision occurs, which is the result of increased river energy by narrowing the river channel in the contact section (Fig. 12). The effects of such an event are observed below and above the contact zone of the landslide system and the river (Costa and Schuster; 1988; Clague and Evans; 1994; Korup, 2005; Schuster, 2006; Hermanns et al. 2009; Kuo et al., 2011; Cebulski, 2014, 2016; Kumar et al., 2019; Wu et al., 2019). Landslide dams most often occur in tectonically active areas. However, they can also occur in areas with less tectonic activity. An example of such an area is the Czech Carpathians, where landslide dam occurrence is connected to the structural-lithological predisposition of flysch morpho-structures (Pánek et al., 2007). Morphometric analyses and field studies in study area have shown only one case of a landslide creating a permanent dam - and several cases of landslides stopping river flow for some time. In mountain areas in Asia and New Zealand, for example, landslide dams occur more frequently, threatening infrastructure and human life. In the investigated $3^{\text {rd }}$ order and $4^{\text {th }}$ order catchments in the Polish flysch Carpathians, there are no landforms threatening either infrastructure or human life. This may be due to the smaller catchments' area, shorter hillslopes and smaller gradients of landslides in the study area as well as the fact that the studied Polish catchments are home to relatively few inhabitants.

The occurrence of landslides and river coupling leads to the transformation of the longitudinal profile of the river. The longitudinal profile can be observed to consist of large steps, which indicate increased accumulation reducing the capacity of the river channel above the contact section, and increased erosion below (Schuster, 2006; Korup et al., 2010) (Fig. 12). The largest changes in the longitudinal profile are observed when two landslides (usually belonging to the point type of contact), located on opposite hillslopes, slide into the river bed and overlap. This creates a barrier and a vast accumulation zone above the two overlapping landslides, blocking the free flow of water and blocking material transport in the downstream direction.

A connection between a landslide system and a valley and river channel is commonly encountered in the studied catchments and affects the development of both systems. Our analyses have shown that the impact of landslides on fluvial processes is much greater than the impact of fluvial processes on landslide development. So-called aggressive landslides have the greatest impact on the development of river channels, and their parameters differ markedly from the parameters of other landslides (Table 6). This indicates the greater potential of aggressive landslides to affect the river system compared to other landslides. Aggressive landslides displace the river channel over the entire length of the contact area and in some cases only over parts of the contact 


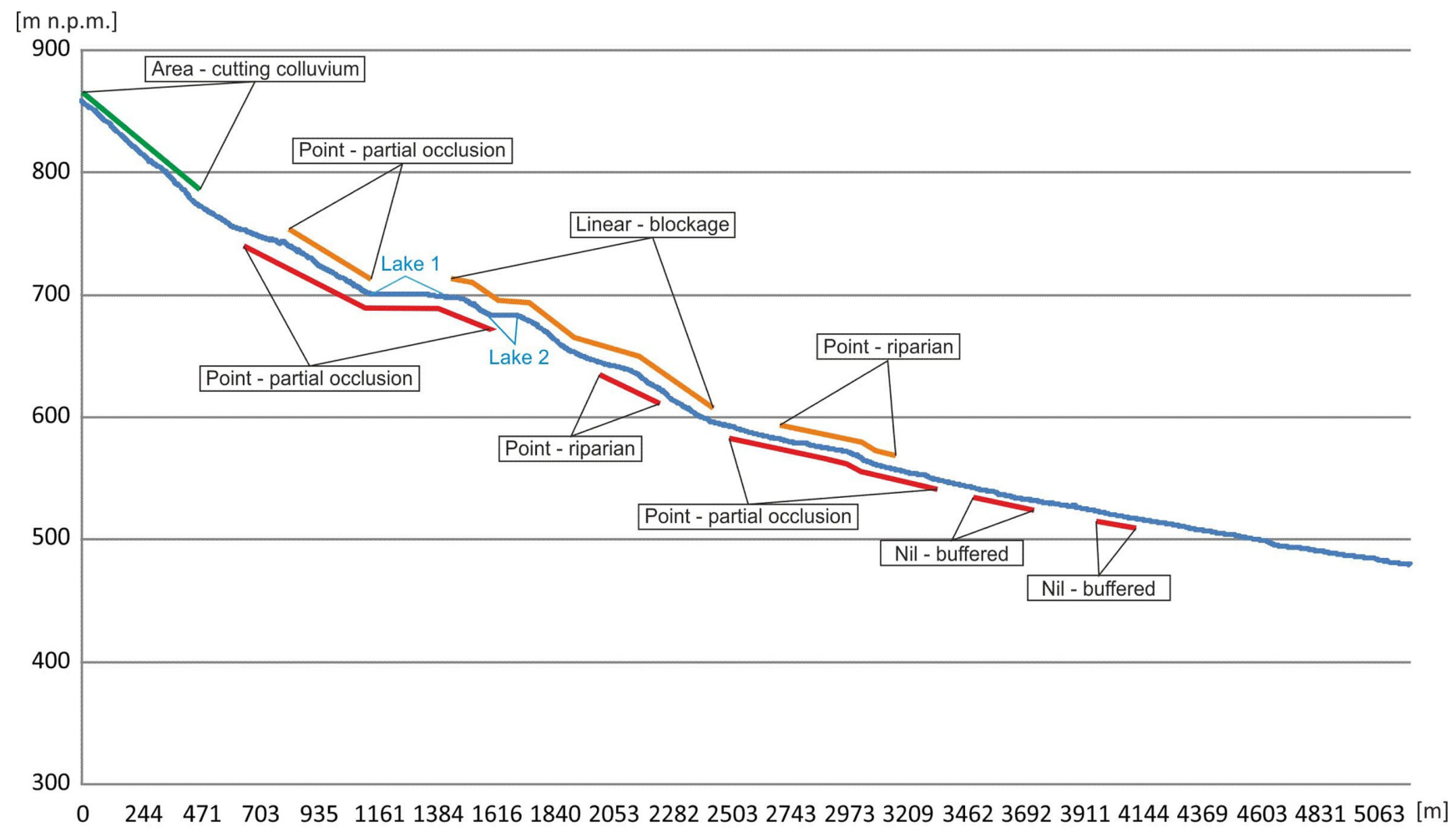

— Landslide on the right slope of the valley _ Landslide in the headwater area

- Landslide on the left slope of the valley

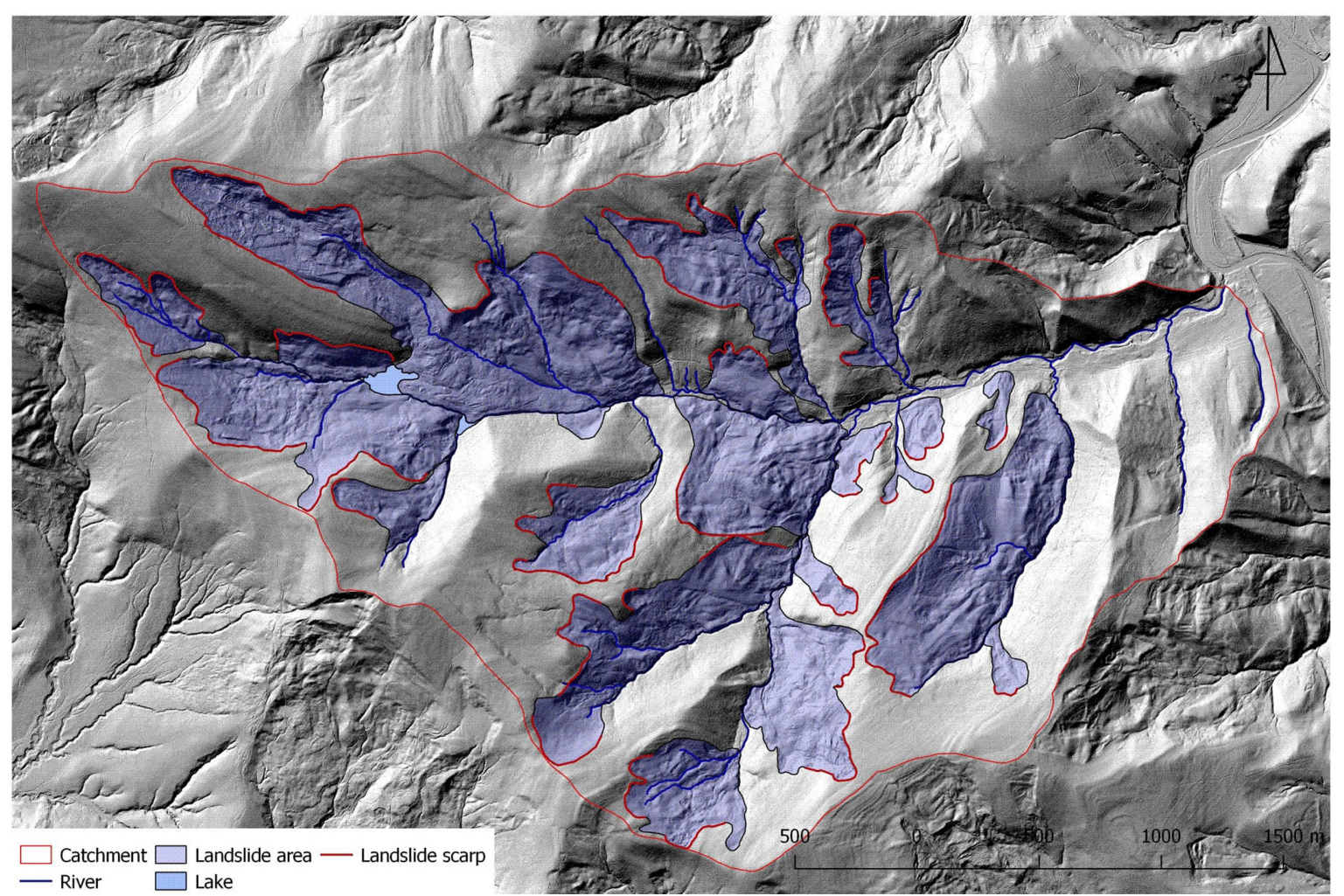

Figure 12. Longitudinal profile (upper panel) and of the Olchowaty River with marked landslides and their types and the Olchowaty River catchment with marked landslides (lower panel).

area. Pushing the colluvium into the river can cause its complete or partial blocking (Fig. 11). This activates both incision and lateral ero- sion. Temporary obstructions to free flow can also cause an accumulation of debris and alluvial deposits above this zone (Fig. 11). In some 
landslides, the fluvial system is interrupted and flow is temporarily blocked, and the river channel is forced to circumnavigate the colluvial masses (Fig. 11). The outcome of the above interactions is asymmetry of the valley floor and river channel (Figs. 11, 12). The valley floor builds up with colluvial masses from the side of the landslide hillslope, and the river channel becomes displaced in the direction of the opposite hillslope.

\section{Conclusion}

Landslide processes strongly impact the development of small mountain river valleys. The hillslopes of catchments are strongly affected by landslides. The percentage of the catchment area affected by landslides varies broadly from $5.5 \%$ to $77 \%$. The majority of landslides (93\%) make contact with the valley floor or river channel. River channels in third-order and fourth-order catchments are largely shaped by landslide processes (from $21.4 \%$ to $39 \%$ of the length of the river network is affected by landslides). Landslides affect the development of valley floors and river channels in a similar manner. Sections of the valley floor and river channel, which are affected by landslide processes, are narrower, and the sinuosity of these river sections is smaller.

Our study has shown that the most common type of interface between a landslide and the river channel is the point type, and the next most common type is the area type. The most common types of geomorphic impact of landslides on the river channel are the riparian type (42.8\%) and the partial occlusion type (29.7\%). Landslides classified as the partial occlusion type of impact on the river channel strongly alter the course of the river channel. Large landslides can block the flow of the river, dividing it into two systems: an accumulative system above the landslide and an erosive system below. Flow blocking most often occurs in the upper part of the catchment.

The Korup classification system (2005) along with some modifications appears to be a useful tool for the analysis of the role of landslides in changes in valley floor relief and in fluvial processes in both midmountains. Landslides reach the valley floor and river channel more frequently in third and fourth order catchments in the Polish flysch Carpathians when compared to the alpine regions of New Zealand.

\section{References}

Bajgier, M., 1994, Rozwój osuwisk w czołowej strefie płaszczowiny magurskiej w dorzeczu górnej Soły. Przegląd Geograficzny, v. 46, pp. 3-4.

Bober, L., 1984, Rejony osuwiskowe w polskich Karpatach fliszowych i ich związek z budową geologiczną regionu. Biuletyn Instytutu Geologicznego, v. 340, pp. 115-161.

Cebulski, J., 2014, The use of Terrestrial Laser Scanner (TLS) to assess the activity of landslides, for example of Bodaki landslide (Beskid Niski Mts.) [in Polish]. Landform Analysis, v. 26, pp. 105-113. doi:org/10.12657/ landfana.026.010

Cebulski, J., 2016, Human impact on the change of direction of river channel migration caused by formation of landslide dam. Studia Geomorphologica Carpatho-Balcanica, v. 1, pp. 5-17.

Chylak, A., and Wrężlewicz, E., 2009, Prognoza oddziaływania na środowisko projektu PGO dla powiatu Żywieckiego. Starostwo Powiatowe w Żywcu, Żywiec.
Clague, J.J., and Evans, S.G., 1994, Formation and failure of natural dams in the Canadian Cordillera. Geological Survey of Canada Bulletin, v. $464,35 \mathrm{p}$.

Costa, J.E., and Schuster, R.L., 1988, The formation and failure of natural dams. Geological Society of American Bulletin, v. 100, pp. 1054 1068, doi:org/10.3133/ofr87392

Crozier, M.J., 2010, Landslide geomorphology: An argument for recognition, with examples from New Zealand. Geomorphology, v. 120, pp. 3 15. doi:org/10.1016/j.geomorph.2009.09.010

Długosz, M., 2011, Landslide susceptibility in the Polish Carpathians [in Polish]. IGiPZ PAN, $230 \mathrm{p}$.

Gorczyca, E., 2004, The transformation of flysch slopes by catastrophic rainfall - induced mass-processes (Lososina River Catchment Basin) [in Polish]. Uniwersytet Jagielloński, Kraków, 101 p.

Haczewski, G., Kukulak, J., and Bąk K., 2007, Budowa geologiczna i rzeźba Bieszczadzkiego Parku Narodowego. Wydawnictwo Naukowe Akademii Pedagogicznej, Kraków, 468 p.

Hermanns, R.L., Blikra, L.H., and Longva, O., 2009, Relation between rockslide dam and valley morphology and its impact on rockslide dam longevity and control on potential breach development based on examples from Norway and the Andes. Long Term Behaviour of Dams, v. 11, pp. 769-774.

Izmaiłow, B., Kaszowski, L., Krzemień, K., and Święchowicz, J., 1995, Rzeźba. In: Warszyńska, J., (Ed.), Karpaty polskie. Przyroda, człowiek i jego działalność. Uniwersytet Jagielloński, Kraków, pp. 23-30.

Jankowski, L., 2015, Objaśnienia do szczegółowej mapy geologicznej Polski 1:50 000, Arkusz Medzilaborce, Łupków i Łupków S, PIG, Warszawa.

Korup, O., 2005. Geomorphic imprint of landslides on alpine river systems, southwest New Zealand. Earth Surface Processes and Landforms, v. 30, pp. 783-800. doi:org/10.1002/esp.1171

Korup. O., Densmore, A.L., and Schlunegger, F., 2010, The role of landslides in mountain range evolution. Geomorphology, v. 120, pp. 77-90. doi:org/10.1016/j.geomorph.2009.09.017

Kumar, V., Gupta, V., Jamir, I., and Chattoraj, S.L., 2019, Evaluation of potential landslide damming: Case study of Urni landslide, Kinnaur, Satluj valley, India. Geoscience Frontiers, v. 10, pp. 753-767. doi:org/ 10.1016/j.gsf.2018.05.004

Kuo, Y.S., Chen, K.T., Wu, H.C., and Shieh, C.L., 2011, Analysis of geometries of landslide dams in Taiwan. International Offshore and Polar Engineering Conference. International Society of Offshore and Polar Engineers 21, $5 \mathrm{p}$.

Margielewski, W., 2008, Wpływ ruchów masowych na współczesną ewolucję rzeźby Karpat fliszowych. In: Starkel, L., Kostrzewski, A., Kotarba, A., and Krzemień, K. (Eds.), Współczesne przemiany rzeźby Polski. IGiGP UJ, Kraków, pp. 69-79.

Ouimet, W.B., Whipple, K.X., Royden, L.H., Sun, Z., and Chen, Z., 2007, The influence of large landslides on river incision in a transient landscape: Eastern margin of the Tibetan Plateau (Sichuan, China). Geological Society of America Bulletin, v. 119, pp. 1462-1476. doi:org/ 10.1130/B26136.1

Pánek, T., Smolková, V., Hradecký, J., and Kirchner, K., 2007, Landslide dams in the northern part of Czech Flysch Carpathians: geomorphic evidence and imprints. Studia Geomorphologica Carpatho-Balcanica, v. 41, pp. 77-96.

Poprawa, D., and Rączkowski, W., 2003, Carpathian landslides (southern Poland) [in Polish]. Przegląd Geologiczny, v. 51, pp. 685-692.

Rączkowski, W., and Mrozek, T., 2002, Activating of landsliding in the Polish Flysch Carpathians by the end of the 20th century. Studia Geomorphologica Carpatho-Balcanica, v. 36, pp. 91-111.

Rączkowski, W., 2007, Zagrożenia osuwiskowe w polskich Karpatach. Przegląd Geologiczny, v. 55, pp. 638.

Schuster, R.L., 2006, Impacts of landslide dams on mountain valley morphology. In: Evans S. G., Mugnozza G. S., Strom A., and Hermanns R. L. (Eds.), Landslides from massive rock slope failure. Springer, Dor- 
drecht, pp. 591-616.

Strahler, A.N., 1964, Quantitative geomorphology of drainage basins and channel networks. Handbook of Applied Hydrology. McGraw-Hill, New York, pp. 4-39.

Uromeihy, A., and Mahdavifar, M.R., 2000, Landslide hazard zonation of the Khorshrostam area, Iran. Bulletin of Engineering Geology and the Environment, v. 58, pp. 207-213. doi:org/10.1007/s100640050076

Van Den Eeckhaut, M., and Hervás, J., 2012, State of the art of national landslide databases in Europe and their potential for assessing landslide susceptibility, hazard and risk. Geomorphology, v. 139, pp. 545558. doi:org/10.1016/j.geomorph.2011.12.006

Wang, H.B., Sassa, K., and Xu W.Y., 2007, Analysis of a spatial distribution of landslides triggered by the 2004 Chuetsu earthquakes of Niigata Prefecture, Japan. Natural Hazards, v. 41, pp. 43-60. doi:org/10.1007/

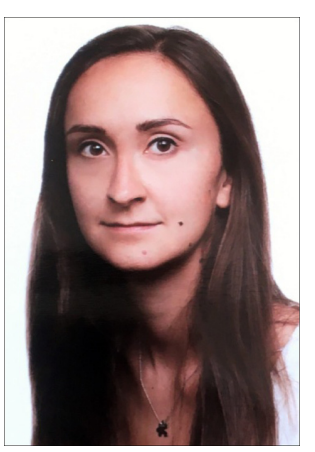

Joanna Caputa GIS Design Professional in Jacobs Engineering. She graduated from Geography at Jagiellonian University in the field of Geomorphology. Her scientific interests focus on the role of landslides in shaping mountain areas. She is using GIS knowledge in environmental science. She presented the results of her research master thesis at an international conference (European Geoscience Union 2019) in Vienna. s11069-006-9009-x

Wojciechowski, T., Borkowski, A., Perski, Z., and Wójcik, A., 2012, Airborne laser scanning data in landslide studies at the example of the Zbyszyce landslide (Outer Carpathians) [in Polish]. Przegląd Geologiczny, v. 60, pp. 95-102.

Wu, L.Z., Deng, H., Huang, R.Q., Zhang, L.M., Guo, X.G., and Zhou, Y., 2019, Evolution of lakes created by landslide dams and the role of dam erosion: A case study of the Jiajun landslide on the Dadu River, China. Quaternary International, v. 503, pp. 41-50. doi:org/10.1016/j.quaint. 2018.08.001

Ziętara, T., 1968, Part player by torrential rains and floods on the relief of Beskid Mountains [in Polish]. Prace Geograficzne IG PAN, v. 22, pp. 55-86.

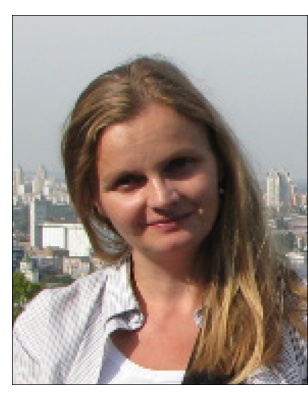

Elżbieta Gorczyca is an associate professor at the Jagiellonian University in Krakow. She completed a Ph.D. thesis concerning the role of mass movement in slope evolution in the course of catastrophic-scale atmospheric precipitation in the Institute of Geography and Spatial Management. Currently her research is focused on the evolution of gravel-bed river channels in mountain areas affected by human impact. She developed a concept of a spontaneous renaturalization of post-regulation river channels. An additional issue studied by her is the role of an Eurasian beaver activity in this process. 